\title{
What Role Can Financial Policies Play in Revitalizing SMEs in Japan?
}

\author{
W. Raphael Lam and Jongsoon Shin
}




\title{
IMF Working Paper
}

Asia and Pacific Department

\section{What Role Can Financial Policies Play in Revitalizing SMEs in Japan? ${ }^{1}$ \\ Prepared by W. Raphael Lam and Jongsoon Shin}

\author{
Authorized for distribution by Stephan Danninger
}

December 2012

This Working Paper should not be reported as representing the views of the IMF. The views expressed in this Working Paper are those of the author(s) and do not necessarily represent those of the IMF or IMF policy. Working Papers describe research in progress by the author(s) and are published to elicit comments and to further debate.

\begin{abstract}
The paper discusses the role the financial sector can play in supporting growth in Japan. While overall credit conditions have been accommodative, credit growth has remained weak, especially for small and medium-sized enterprises (SMEs). Firm-level SME data and sectoral corporate balance sheets show that many SMEs have faced structural challenges of high leverage and low profitability. Moreover, the global financial crisis has weakened the financial position across SMEs, particularly for those with low credit worthiness. These challenges are closely related to low availability of riskcapital and the pervasiveness of credit support measures. This paper argues that to encourage the supply of risk-based capital, costly government support measures should be phased out and SME restructuring be accelerated. Efforts are also needed to deepen capital markets to enhance risk capital availability and address regulatory barriers to starting businesses. In that regard, addressing SME weaknesses would improve private investment, enhance firm productivity, and lift growth.
\end{abstract}

JEL Classification Numbers: G21, G32, G01

Keywords: Small and medium-sized enterprises (SMEs), credit guarantees

Authors’ E-Mail Address:WLam@imf.org and JShin2@imf.org

\footnotetext{
${ }^{1}$ We are thankful for the assistance by Mr. Tsukada and Mr. Takahashi of the Credit Risk Database in data access. We also acknowledge the comments from seminar participants from the Bank of Japan, Financial Service Agency, Ministry of Finance, Ministry of Economy, Trade, and Industry, and the Cabinet Office.
} 


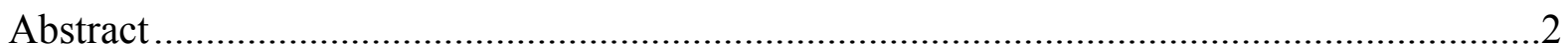

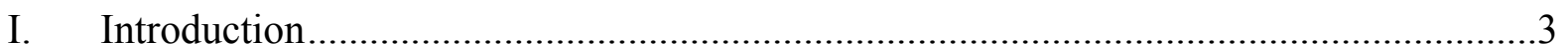

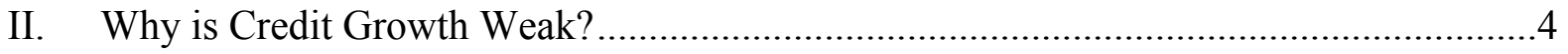

III. How Did SMEs Fare During the Global Financial Crisis? ..........................................8

IV. Growth Challenges of SMEs: Slow Restructuring and Limited Availability of

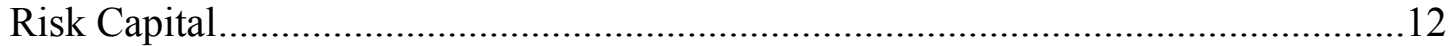

A. Why Have SMEs Been Slow to Restructure? ...................................................14

B. Why is the Access and Availability of Risk-Based Capital Limited?....................16

V. Policy Options to Support Credit Growth............................................................19

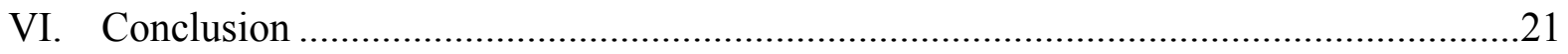

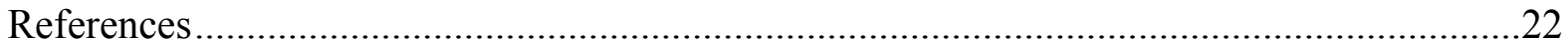

Tables

1. Summary Statistics of the Corporate Sector-By Industry and Capital Size ......................7

2. SMEs' Performance and Soundness, by Risk Ratings..................................................8

3. Regression Estimates on Corporate Adjusted Net Profit .................................................9

4. Government Credit Guarantee Schemes ..................................................................... 14

Figures

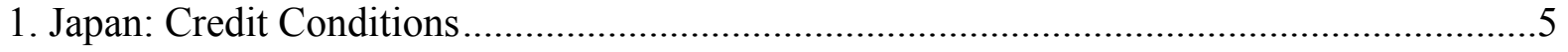

2. Japan: Factors Contributing to Weak Credit Growth ....................................................6

3. Estimated Coefficients on Interactive Dummy Variables .............................................9

4. Financial Performance of SMEs, by Risk Groups ................................................... 11

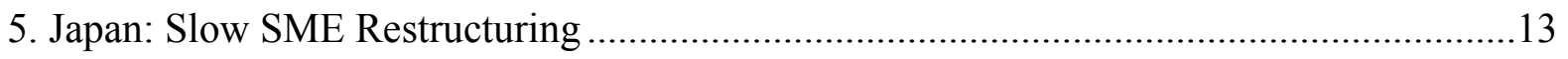

6. Limited Availability of Risk-based Capital and Business Transfers ...............................17

7. Japan: Market Practices and Regulatory Factors that Limit Risk-based Capital................19 


\section{INTRODUCTION}

1. Japan's small and medium-sized enterprises (SMEs) have been a major source of employment and growth, but their role in the economy has been hindered by their weak performance. The SME sector accounts for nearly 70 percent of total employment and over half of manufacturing value-added. Businesses span many industries and have historically served as key suppliers to large manufacturing firms and represent the backbone of the service sector. Over the last decade, however, SMEs have no longer been a thriving source of growth. The profitability and investment of SMEs have declined significantly and business registration of SMEs (in net terms) has been stagnant since the global financial crisis, despite very accommodative financing conditions.

2. This paper explores reasons behind the weak performance among SMEs, particularly during the global financial crisis, and discusses what role financial sector policies play in revitalizing SMEs. The focus on the financial sector policies is motivated by widespread evidence that nonviable SMEs were kept afloat due to various credit support policies and resource misallocation (Caballero, Hoshi, and Kashyap, 2006; Uesugi, 2008; Kwon, Narita, and Narita, 2009) during Japan's lost decade, which hampered businesses renewal. The paper poses three questions:

$>$ What are the principal reasons of weak credit growth since the Lehman shock, especially among SMEs?

Dhy has SME restructuring been so slow and risk capital so limited?

$>$ What financial sector policies are needed to boost growth and what gains can be expected?

3. Credit growth of SMEs remains relatively subdued largely because of weak growth prospects and structural weaknesses among SMEs. Weak growth prospects with consumer demand slowing and stagnant land prices, particularly outside the metropolitan areas, have shrunk SMEs business opportunities and deterred capital investments. Despite accommodative financing conditions, real interest cost has remained high due to lingering deflation. In addition, weak credit growth among SMEs, in part, is attributable to their structural weaknesses, with nonviable SMEs having been kept afloat partly by low interest rates and the help of public credit support measures (e.g., full-value credit guarantees). Firmlevel SME data and sectoral corporate balance sheets show that many SMEs have high leverage and low profitability. The global financial crisis has weakened the financial position across SMEs further, particularly for those with low credit worthiness. Finally, regulatory barriers and the lack of market development have also played a role, including by adding to the costs of starting a business and limiting the types of credit available.

\section{Despite their low profitability and high leverage, there have been only limited} restructuring or exits of nonviable SMEs. Creditors and nonviable SMEs have little incentive to restructure loans as refinancing is easy and several credit support measures (e.g., full-value credit guarantees) have made it less attractive for voluntary workouts or business 
transfers. In addition, recognizing losses would hit banks' profit and capital, especially for smaller regional/shinkin banks that generally lack expertise on large-scale business restructuring and face higher nonperforming loans (Watanabe, 2012). The slow pace of restructuring, along with the heavy reliance of collaterals and personal guarantees in loans, has limited the availability of risk-based capital.

\section{To support growth, financial policies need to address the impediments to credit} growth. This paper argues that to encourage the supply of risk-based capital, policies should accelerate SME restructuring, costly government support measures should be phased out, and the capital base of smaller banks be strengthened to foster consolidation. At the same time, efforts are needed to deepen capital markets to improve the availability of risk capital and address regulatory barriers to starting businesses.

6. The paper is organized as follows. It first discusses reasons behind weak credit growth and present evidence of SME structural weaknesses using firm-level data and sectoral corporate balance sheets. Then, it illustrates the reasons and implications of slow progress on SME restructuring and limited availability of risk capital. Finally, the paper discusses policy options to resolve these problems and quantifies possible growth gains.

\section{Why IS CREDit GROWTH WeAK?}

\section{Credit growth remains weak, even though banks' lending attitudes and corporate} bond markets have largely recovered from the low points following the Lehman crisis. Firms' perception (e.g., Bank of Japan's Tankan survey) suggests that financial institutions have improved their lending attitudes for all types of firms (Figure 1). By late 2011, the diffusion index had recovered to positive territory for the first time since the Lehman crisis in late 2008, but bank's attitudes to larger firms have recovered more than those for small firms. In addition, banks have plenty of liquidity to lend, with loan-to-deposit ratios at historic lows (near 70 percent) and the lowest among advanced countries. Funding conditions in debt market have also been favorable as bond spreads returned to pre-crisis levels (less than $1 / 2$ percent for AA-rated debt). Credit growth picked up initially following the global crisis as large firms borrowed for precautionary purposes, but barely grew in early 2012 for large corporations and fell by 1 percent y/y for SMEs, though the decline has narrowed lately. This is in line with other indicators, such as the Tankan indices for credit demand by firms and households, which have remained fairly weak after a short-lived bounce-back after the earthquake. 
Figure 1. Japan: Credit Conditions
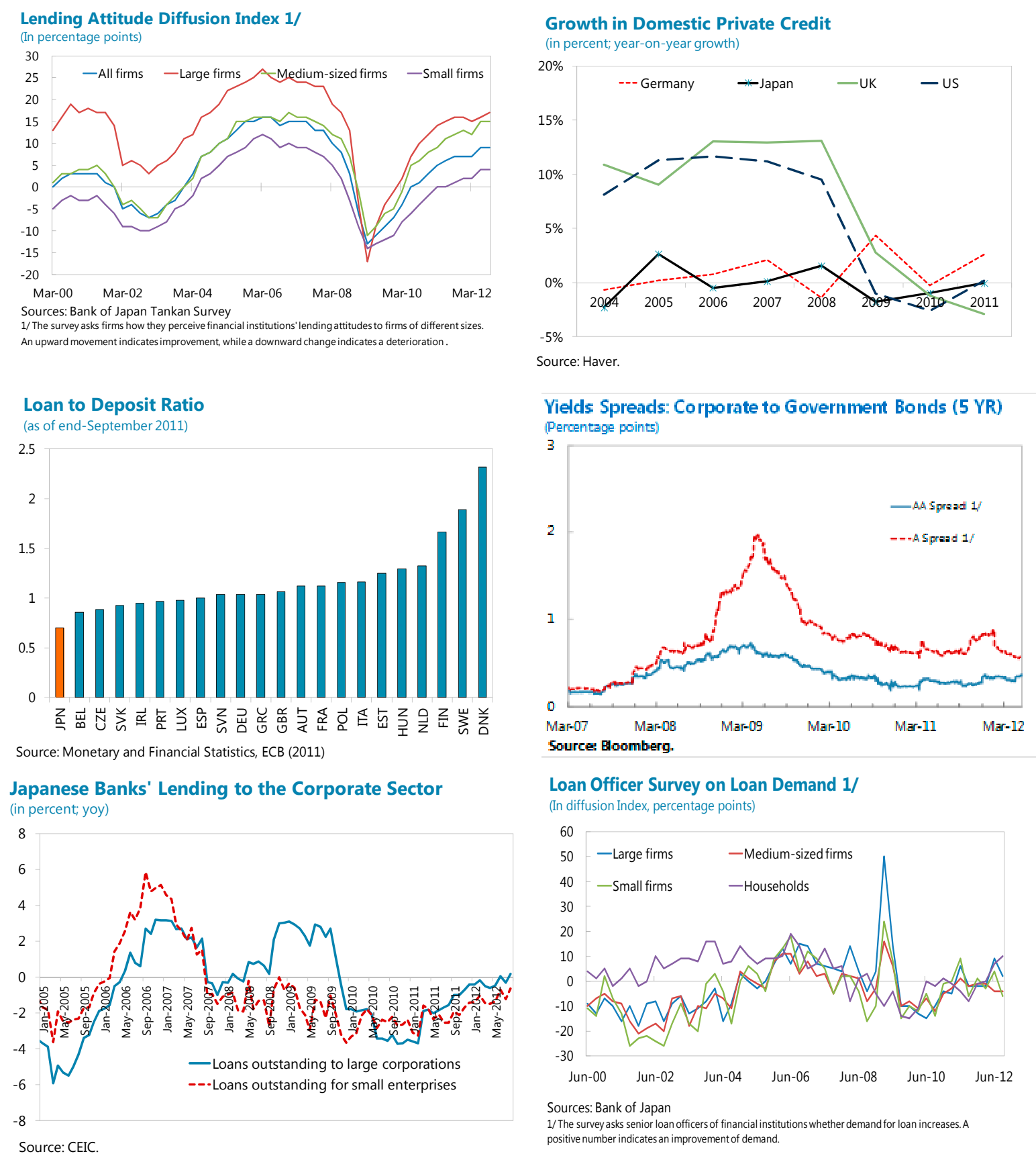

\section{Several factors have contributed to weak credit growth despite accommodative} financing conditions. These include relatively weak economic growth, deleveraging following the crisis, and the weakness of SMEs' balance sheets.

- Macroeconomic conditions. Weak growth prospects have deterred firms from borrowing for capital investment. Consumer confidence has weakened, putting durable goods consumption in decline, while the stagnant land and equity prices depressed household wealth. Furthermore, lingering deflation and interest rates at zero lower bound limited the decline of real interest rates compared with other countries, thereby not providing much 
stimulus to credit demand (Figure 2). Structural factors such as population aging and the shrinking rural economy (serviced mainly by regional banks) have also contributed to weak credit demand.

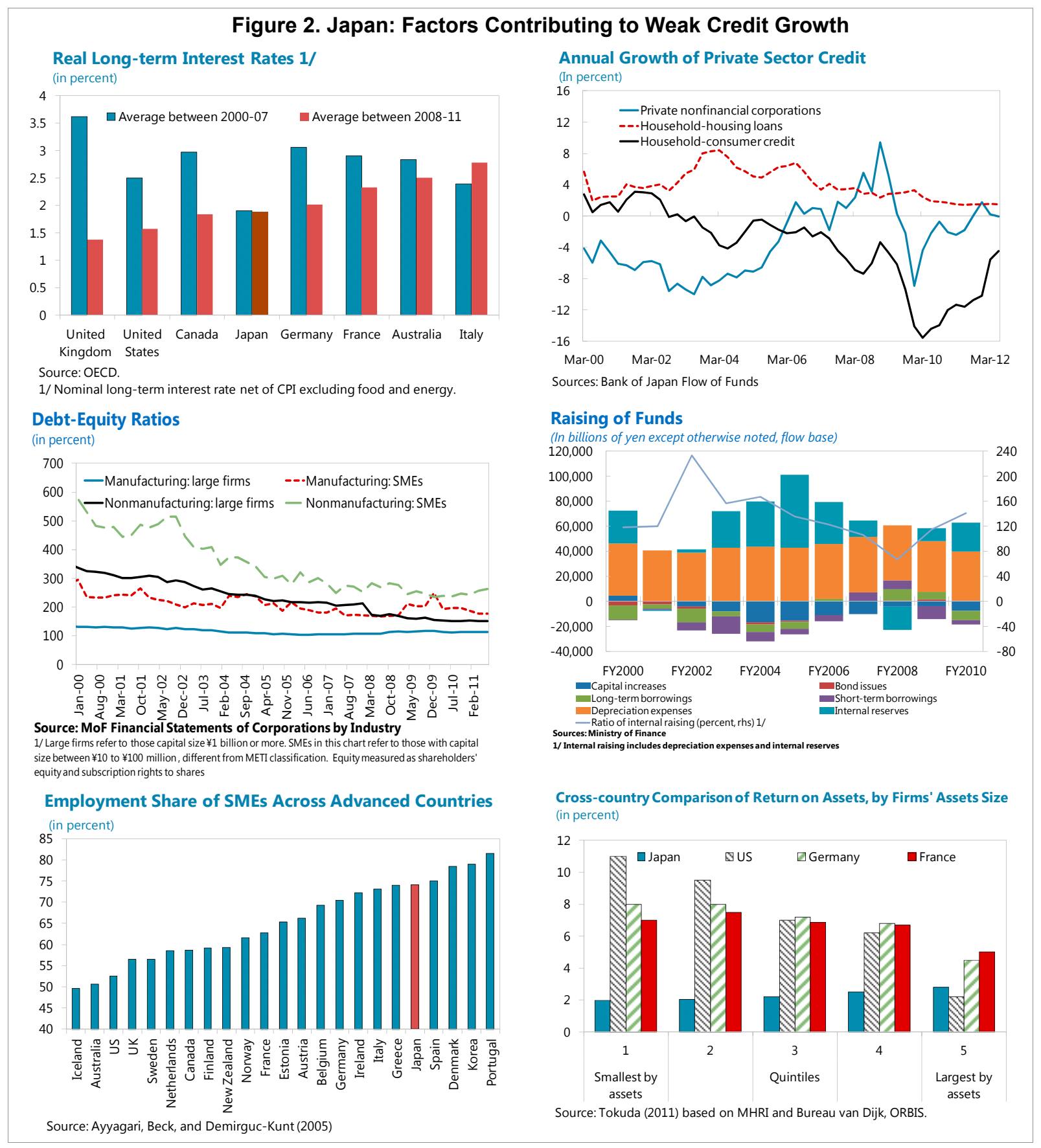

- Firms deleveraging. Slow credit growth is also related to firms' deleveraging efforts over the past years. Firms have scaled back their capital investment and shifted towards internal financing to respond to rising debt burden in the face of falling output. Following the global financial crisis, internal financing (through retained earnings and depreciation) 
increased from 60 percent of external financing to 150 percent during 2008-10, in part reflecting a wish to further deleverage, similar to firms in other advanced countries.

- Low SME profitability and legacy effects. SMEs in Japan have a lower net profit margin (adjusted by firms' capital ratio) at about 1 1/2 percent than large firms, and far below the average of 8 percent for other advanced economies (Tokuda, 2011). SMEs have been deleveraging, particularly in the nonmanufacturing sector, but they still have high debt (at 250-300 percent of equity; 2 $\frac{1}{2}$ times higher than large firms) and loans to SMEs still account for about half of the bank credit (Table 1). In addition, those SMEs with credit guarantees tend to take longer to repay current debt and are more likely to incur losses (text charts).

\begin{tabular}{|c|c|c|c|c|c|c|c|c|c|c|c|c|}
\hline \multirow{3}{*}{$\begin{array}{l}\text { Sector } \\
\text { Size of capital 1/ } \\
\text { Summary statistics } 2 /\end{array}$} & \multicolumn{4}{|c|}{ All } & \multicolumn{4}{|c|}{ Manufacturing } & \multicolumn{4}{|c|}{ Nonmanufacturing } \\
\hline & All & Large & Medium & Small & All & Large & Medium & Small & All & Large & Medium & Small \\
\hline & & & & & & & & & & & & \\
\hline Capital / Total assets & 6.7 & 9.6 & 4.0 & 3.8 & 7.9 & 10.4 & 3.9 & 3.5 & 6.1 & 9.1 & 4.0 & 3.9 \\
\hline Return on assets & 0.8 & 0.9 & 0.9 & 0.7 & 1.0 & 1.1 & 1.1 & 0.9 & 0.8 & 0.8 & 0.8 & 0.7 \\
\hline Debt equity ratio & 222.1 & 168.2 & 278.9 & 307.3 & 138.6 & 114.9 & 177.2 & 208.1 & 288.9 & 230.4 & 342.5 & 348.2 \\
\hline Interest rate coverage (in times) & 1.0 & 0.9 & 1.0 & 1.0 & 1.0 & 1.2 & 1.0 & 1.0 & 1.0 & 0.9 & 1.0 & 1.0 \\
\hline Adjusted net profit margin $3 /$ & 3.3 & 6.2 & 1.6 & 1.5 & 4.4 & 6.6 & 1.9 & 1.4 & 3.0 & 6.0 & 1.6 & 1.6 \\
\hline Labor productivity 4/ & 0.3 & 0.8 & 0.3 & 0.2 & 0.4 & 0.4 & 0.4 & 0.2 & 0.3 & 0.8 & 0.3 & 0.2 \\
\hline $\begin{array}{l}\text { Sources: Ministry of Finance and staff esti } \\
1 \text { / by size of capital, which provides a prox } \\
\text { 2/ Averages from } 2000 \text { by sector and size } \\
\text { 3/ Net profit margin adjusted by the capit } \\
\text { 4/ Value-added per employee }\end{array}$ & $\begin{array}{l}\text { firm size. } \\
\text { ital. } \\
\text { o relative }\end{array}$ & to its sed & toral mean. & & & & & & & & & \\
\hline
\end{tabular}

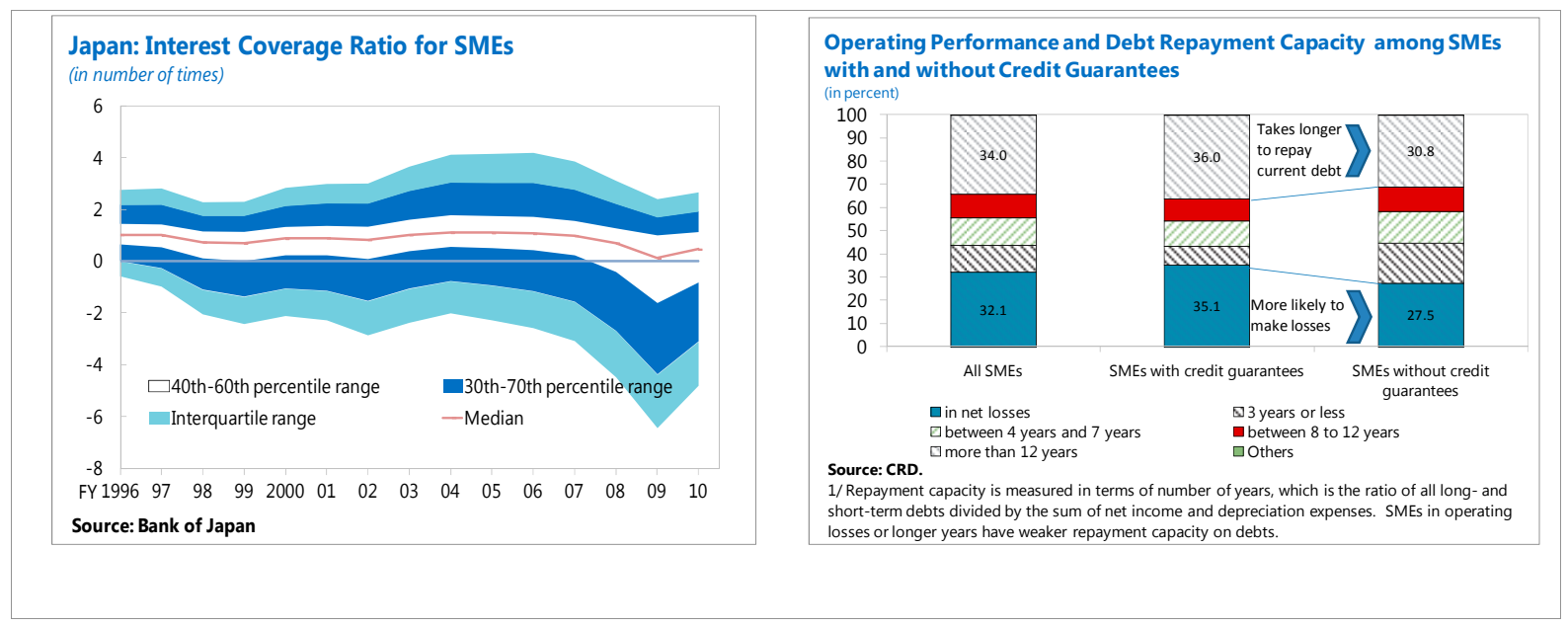

9. Among these three factors, the constraints on SMEs, especially during the global crisis, are not well understood. Financial positions among SMEs vary widely (Table 2). SMEs with low credit worthiness (higher risk groups) tend to incur losses, accumulate more debt, and have limited capacity to repay their debts. Questions remain to what extent these challenges have worsened or eased during the global financial crisis across SMEs as credit support measures were introduced? 
Table 2. SMEs' Performance and Soundness, by Risk Ratings

\begin{tabular}{|c|c|c|c|c|c|}
\hline & $\begin{array}{c}\text { Debt equity } \\
\text { ratio } 1 /\end{array}$ & $\begin{array}{l}\text { Return on } \\
\text { assets 2/ }\end{array}$ & $\begin{array}{c}\text { Interest } \\
\text { coverage } \\
\text { ratio }\end{array}$ & $\begin{array}{c}\text { Borrowing } \\
\text { cost 2/ }\end{array}$ & $\begin{array}{c}\text { Repayment } \\
\text { capacity } 3 /\end{array}$ \\
\hline Full sample & 1.75 & 0.30 & 0.82 & 2.21 & 0.09 \\
\hline After 2008 & 1.28 & 0.14 & 0.44 & 2.06 & 0.08 \\
\hline Before 2008 & 1.98 & 0.38 & 0.93 & 2.29 & 0.09 \\
\hline \multicolumn{6}{|l|}{ Risk rating 4/ } \\
\hline 1 & 1.24 & 3.57 & 8.39 & 1.79 & 0.39 \\
\hline 2 & 1.99 & 1.59 & 3.01 & 1.97 & 0.18 \\
\hline 3 & 2.56 & 0.92 & 1.76 & 2.06 & 0.12 \\
\hline 4 & 2.93 & 0.57 & 1.19 & 2.02 & 0.09 \\
\hline 5 & 2.72 & 0.31 & 0.83 & 2.00 & 0.07 \\
\hline 6 & 2.28 & 0.15 & 0.53 & 2.09 & 0.06 \\
\hline 7 & 1.70 & 0.07 & 0.31 & 2.23 & 0.05 \\
\hline 8 & 0.64 & 0.03 & 0.19 & 2.41 & 0.04 \\
\hline 9 & -1.32 & 0.00 & 0.09 & 2.65 & 0.03 \\
\hline 10 & -1.74 & -1.85 & -0.30 & 2.99 & 0.02 \\
\hline \multicolumn{6}{|c|}{$\begin{array}{l}\text { Source: CRD. } \\
1 / \text { Negative debt equity ratios and interest rate coverage indicates negative equity } \\
\text { and net losses. } \\
2 / \text { in percent. } \\
3 \text { / Repayment capacity is defined as a ratio of the sum of net income and } \\
\text { depreciation to debt level. } \\
4 \text { / Lower risk rating number indicates higher creditworthiness. }\end{array}$} \\
\hline
\end{tabular}

\section{How Did SMEs Fare During The Global Financial Crisis?}

10. SMEs entered the global crisis from a position of relative weakness. Underlying profitability had been on a decline since the 1990s. This result can be derived from analyzing the corporate performance in a sectoral panel between 1960Q1 to 2011Q3. Regression analysis of business profitability (Table 3 ) shows that, as expected, higher leverage (debtequity ratio) in lags is generally associated with lower business profitability. It further suggests that manufacturing and larger firms have higher profit margins than nonmanufacturing and smaller firms after controlling for cyclical fluctuations of demand (through yearly dummy variables). ${ }^{2}$ By interacting the yearly dummy variables with those for firm size, the empirical model can identify additional structural differences in profitability across firm size and sectors (Figure 3). Two results emerge:

$>$ Regarding firm size (left panel of Figure 3), the profitability premium point between large and small and medium-sized firms widened steadily to about 2-3 percentage points over the last 30 years. Current profitability levels for small enterprises are at historic lows, while that of large enterprises has an increasing trend since the early 1970s, only temporarily falling during the peak of the global financial crisis.

\footnotetext{
${ }^{2}$ In essence, the macroeconomic effects, such as economic growth or changes in the exchange rate, are captured by the inclusion of yearly dummy variables. The yearly dummy variables can be interacted with other variables of interests to test their time specific impact without losing too many degrees of freedom in the estimation.
} 
$>$ Until recently, manufacturing firms tended to have higher profitability than non manufacturing sector, which recorded a steady improvement in profitability in the 2000s (see also Ogawa, Mika, and Tokutsu, 2012) (right panel of Figure 3). The decline of the profit margin in the manufacturing sector could be due to appreciating pressures of the yen and weaker external demand (relative to domestic demand) as a sizeable portion of manufacturing firms export their products overseas.

Table 3. Regression Estimates on Corporate Adjusted Net Profit

\begin{tabular}{|c|c|c|c|c|c|c|c|c|}
\hline \multicolumn{9}{|c|}{ Dependent variable: Adjusted net profit margin 1/ } \\
\hline \multirow{2}{*}{$\begin{array}{l}\text { Sample period } \\
\text { Specifications }\end{array}$} & \multicolumn{4}{|c|}{ Full sample (1960q1 to 2011 q3) } & \multicolumn{4}{|c|}{ Subsample (1980Q1 to 2011Q3) } \\
\hline & $(1)$ & $(2)$ & (3) & (4) & (1) & $(2)$ & (3) & -4 \\
\hline \multirow[t]{2}{*}{ constant } & 3.76 & 4.31 & 1.65 & 2.83 & 2.82 & 3.00 & -0.61 & 2.57 \\
\hline & $(0.36)$ & (0.49) & $(0.60)$ & $(0.27)$ & $(0.39)$ & $(0.40)$ & $(0.42)$ & $(0.28)$ \\
\hline \multirow[t]{2}{*}{ Lagged debt-equity ratio } & -0.26 & -0.24 & -0.27 & 0.00 & -0.15 & -0.14 & -0.20 & 0.00 \\
\hline & $(0.00)$ & $(0.00)$ & $(0.00)$ & $(0.00)$ & $(0.00)$ & $(0.00)$ & $(0.00)$ & $(0.00)$ \\
\hline \multirow{2}{*}{ Lagged value-added per employee } & 1.60 & 1.47 & 1.43 & 1.31 & 3.31 & 3.25 & 3.16 & 1.43 \\
\hline & $(0.44)$ & $(0.45)$ & (0.45) & $(0.31)$ & $(0.47)$ & (0.52) & $(0.46)$ & $(0.33)$ \\
\hline \multirow[t]{2}{*}{ Lagged interest cost } & 0.05 & 0.04 & -0.02 & -0.09 & -0.14 & -0.14 & -0.24 & -0.03 \\
\hline & $(0.02)$ & $(0.02)$ & $(0.03)$ & $(0.05)$ & $(0.02)$ & $(0.02)$ & (0.03) & $(0.05)$ \\
\hline \multirow[t]{2}{*}{ Lagged account receivables ratio $2 /$} & - & -0.05 & - & - & - & -0.01 & - & - \\
\hline & - & $(0.02)$ & - & - & - & (0.03) & - & - \\
\hline \multirow[t]{2}{*}{ Lagged current liabilities ratio } & - & - & 0.05 & - & - & - & 0.08 & - \\
\hline & - & - & $(0.01)$ & - & - & - & $(0.01)$ & - \\
\hline \multirow[t]{2}{*}{ Dummy - manufacturing } & 0.32 & 0.53 & 0.10 & 0.06 & 0.54 & 0.59 & -0.04 & 0.09 \\
\hline & $(0.15)$ & $(0.19)$ & $(0.13)$ & $(0.03)$ & $(0.15)$ & (0.19) & $(0.11)$ & $(0.03)$ \\
\hline \multirow[t]{2}{*}{ Dummy - medium-sized } & -1.65 & -1.77 & -2.05 & -1.96 & -1.44 & -1.50 & -2.09 & -1.97 \\
\hline & $(0.21)$ & $(0.24)$ & $(0.26)$ & (0.19) & $(0.23)$ & $(0.10)$ & $(0.29)$ & (0.19) \\
\hline \multirow[t]{2}{*}{ Dummy - small-sized } & -1.73 & -1.75 & -2.01 & -1.75 & -1.17 & -1.19 & -1.39 & -1.86 \\
\hline & $(0.23)$ & $(0.24)$ & $(0.26)$ & $(0.20)$ & $(0.27)$ & $(0.28)$ & $(0.20)$ & $(0.20)$ \\
\hline Dummy - yearly 4/ & - & - & - & Yes & - & - & - & Yes \\
\hline \multicolumn{9}{|l|}{ Interactive terms: 4/ } \\
\hline Dummy(yearly)*Dummy(firm size) & - & - & - & Yes & - & - & - & Yes \\
\hline Dummy(yearly)*Dummy(sector) & - & - & - & Yes & - & - & - & Yes \\
\hline Number of observations & 1026 & 1026 & 1026 & 1026 & 762 & 762 & 762 & 762 \\
\hline F-statistics & 158.3 & 142.1 & 139.3 & 65.0 & 206.8 & 173.7 & 201.4 & 61.1 \\
\hline Adjusted R-squared & 0.54 & 0.54 & 0.55 & 0.88 & 0.69 & 0.69 & 0.72 & 0.88 \\
\hline
\end{tabular}

$1 /$ Net profit margin adjusted by the capital ratio relative to its sectoral mean.

2/ Account receivables to sales

3/ Numbers in parentheses are statistically significant at the 5 percent level.

4/ Results are illustrated in separate charts given there are over 40 yearly dummy variables.

\section{Figure 3. Estimated Coefficients on Interactive Dummy Variables}

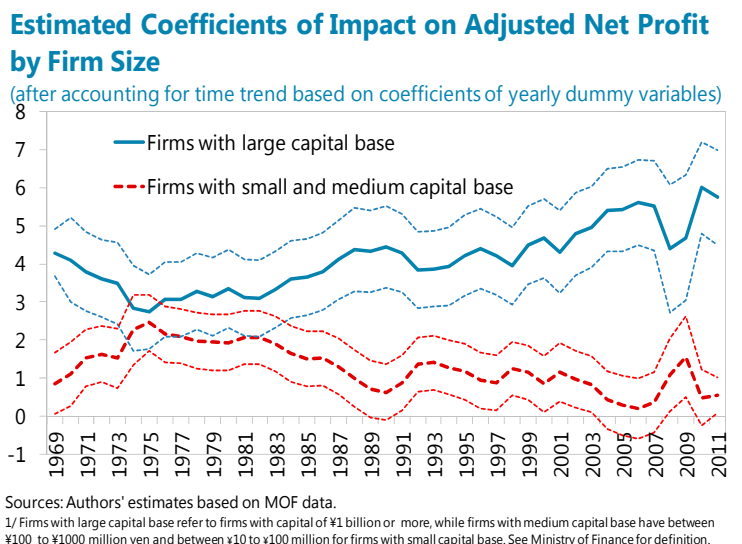

Estimated Coefficients of Impact on Adjusted Net Profit, by sector

(after accounting for time trend based on coefficients of yearly dummy variables)

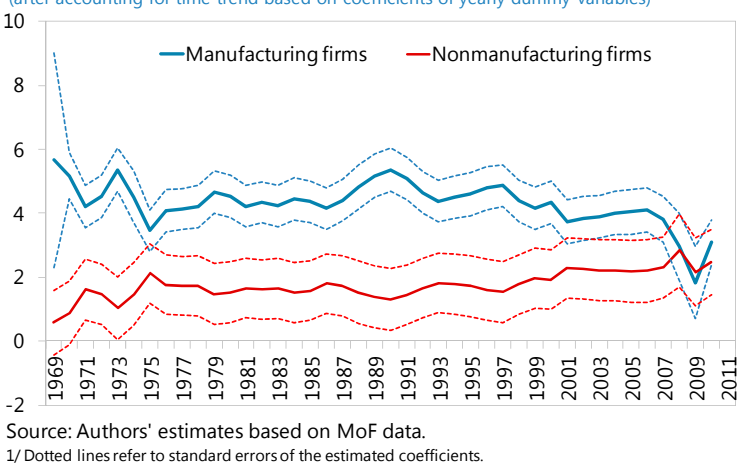


11. The global financial crisis further weakened the financial performance across SMEs, particularly for those with low credit worthiness. Using firm-level data from the Credit Risk Database (CRD), several financial indicators can be computed across risk groups before and after the global financial crisis in 2008 (Figure 4). The risk groups are divided into ten deciles according to the SME credit worthiness (with "1" indicating the best credit worthiness), which are based on CRD analysis of credit scores and other financial variables. Financial performance varies over the risk groups as indicated in Table 2. On average, highrisk SMEs tend to borrow more than the low-risk SMEs. The main findings are:

$>$ The median return on assets has fallen across all risk classes after the global financial crisis. The decline for SMEs with good credit has been marginal, while the decline for those with low creditworthiness (risk groups $7^{\text {th }}-10^{\text {th }}$ deciles) was substantial and continued after 2008. In addition, the overall median return on assets has been low at about 1 percent, in line with previous studies.

$>$ The debt-equity ratio also deteriorated significantly for SMEs under high risk groups. Specifically, the median debt-equity ratio has turned negative - an indication of negative equity - for weak SMEs that fall between $7^{\text {th }}$ and $10^{\text {th }}$ risk groups. For those SMEs with good credit worthiness, the debt-equity ratio has slightly declined to about 2 times on average, in part reflecting the deleveraging and less needs of debt financing.

$>$ Losses incurred by high-risk SMEs have reduced the repayment capacity on debts, as shown in the decline of interest rate coverage after the global financial crisis. Especially, SMEs in risk groups $8^{\text {th }}-10^{\text {th }}$ have had difficulties meeting their interest obligations on average before the global financial crisis (i.e., interest coverage close to zero) and were unable to do so after 2008 as their coverage ratio turned negative.

12. The rise in credit risk after the global financial crisis, however, was not accompanied by a wider interest differentiation (Figure 4). Borrowing costs have eased across the board for SMEs, but interest rates do not seem to fully reflect the underlying credit risks among weak SMEs. The median borrowing costs for SMEs have declined by 20-30 basis points after the global financial crisis across risk groups by similar magnitudes. This appears puzzling given SMEs in risk groups $8^{\text {th }}-10^{\text {th }}$ have fared much worse after the global financial crisis. Their borrowing costs, if lenders accounted fully for higher credit risks, should have increased sharply and offset the broad decline of interest rates. One explanation is that the crisis measures, such as the safety-net lending and special credit guarantees have eased financing conditions for these SMEs (see next section). On average, the difference in median borrowing costs between the lowest and highest risk groups is about 100 basis points and appears small compared with the large differences in operating performance between these groups (Table 2 and Figure 4).

13. Further analysis suggests borrowing costs for SMEs with low credit worthiness have fallen below banks' breakeven rate. In the lower panels of Figure 4, we illustrate a comparison of actual SME borrowing costs and the implicit interest rate that would keep banks/lenders breakeven across risk groups before and after the global financial crisis. Firms' loanable rates (thick dotted lines) show the interest rate that firms are able to afford-derived from interest coverage data. Actual borrowing costs (semi-dotted lines), as indicated before, are increasing but largely flat across risk groups. Bank's breakeven rates (thin dotted lines) were estimated by Shirota, Imakubo, and Nishioka (2011) and implicitly accounted for funding costs and credit risks based on the information on nonperforming loans and CRD data. 
Figure 4. Financial Performance of SMEs, by Risk Groups 1/ 2/

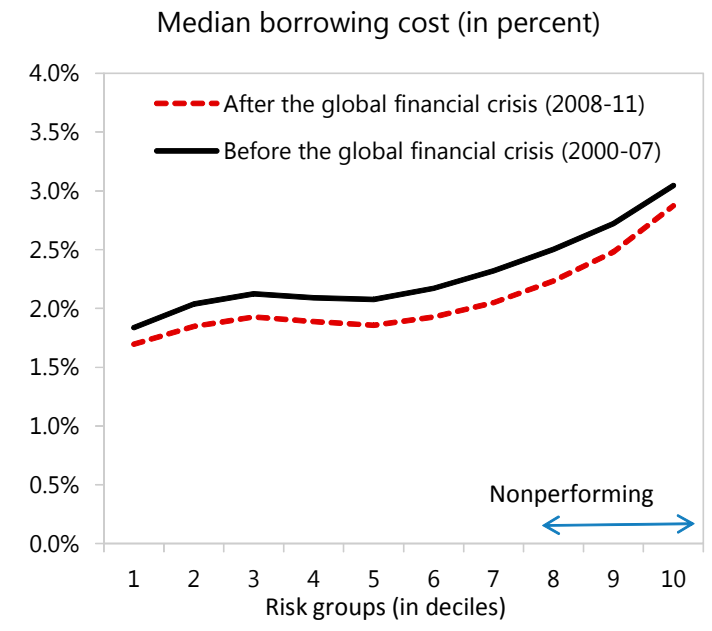

Median debt-to-equity ratio

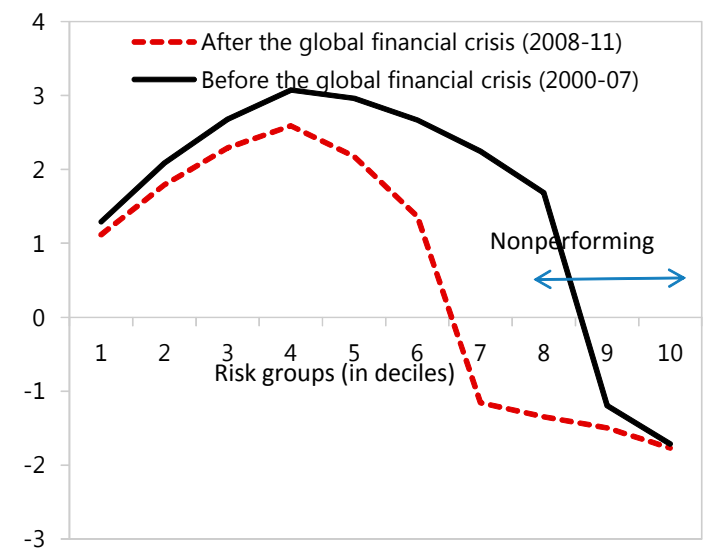

Median interest rate coverage (in times)
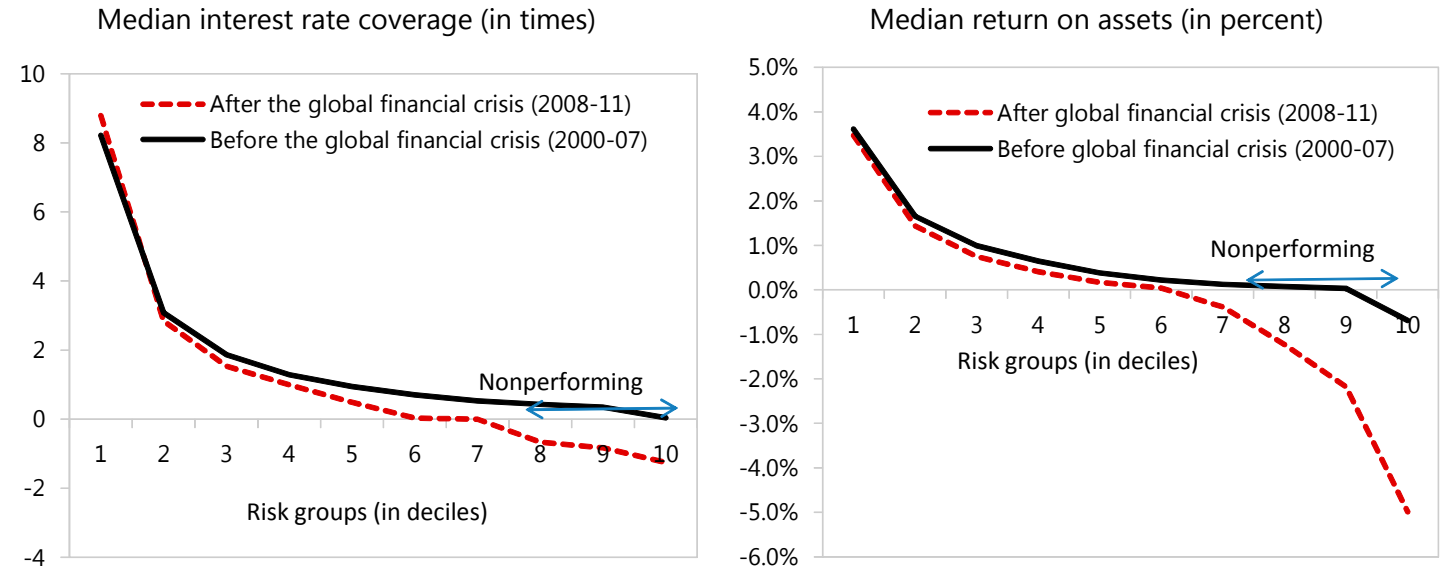

Demand and Supply of loanable funds (in percent)

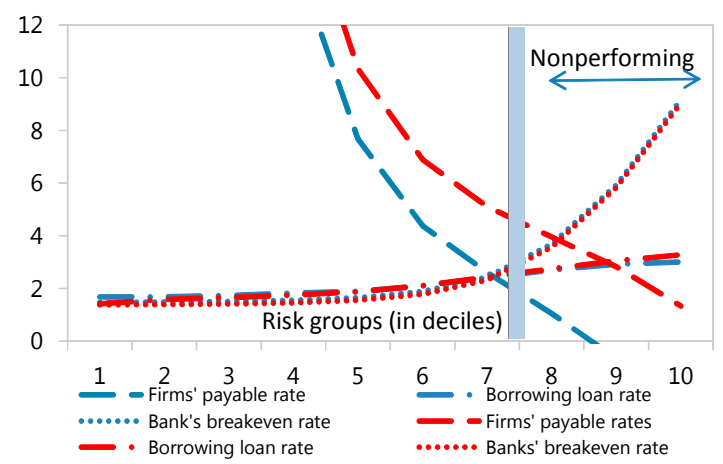

Demand and Supply of loanable funds (in percent)

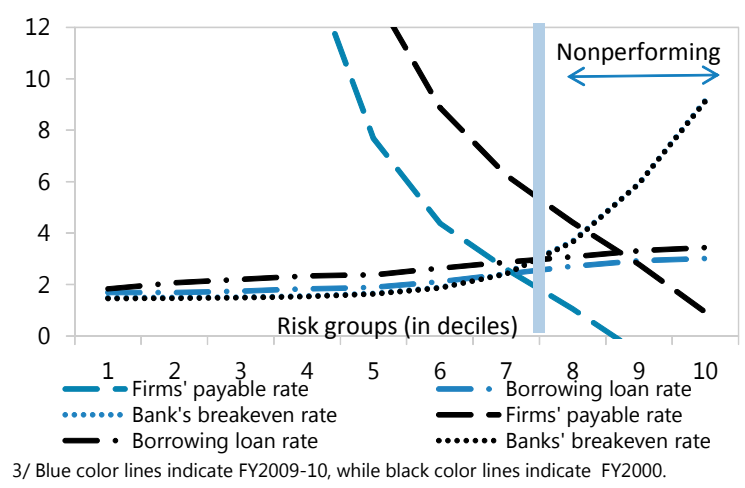

3/ Blue color lines indicate FY2009-10, while red color lines indicate FY2005.

Sources: Credit Risk Database, Bank of Japan, and authors' estimates.

$1 /$ The credit worthiness of the SMEs is decomposed into ten risk group deciles by the Credit Risk Database according to the credit scores of SMEs, with "1" indicating the best credit worthiness and "10" the least. Groups "8" to "10" indicate nonperforming SMEs.

2/ Data span from 2000-11 annually for SMEs and are separated to two sample periods, prior to the global financial crisis (2000-07) and after the global financial crisis (2008-11). Figures indicate median values unless specified. 


\section{Several observations are noted:}

i. SME borrowing rates have exceeded slightly the banks' breakeven rates for strong SMEs, indicating a thin but positive net interest margin, while the borrowing costs of weak SMEs are far below banks' breakeven rate once accounting for credit risks. The difference includes credit risks that were borne elsewhere, such as through credit guarantees.

ii. Firms' loanable rate for risk groups $8^{\text {th }}-10^{\text {th }}$ are on average lower than the actual borrowing costs of SMEs, similar to the previous findings on the interest coverage of SMEs in those risk groups. This implies that these SMEs are, on average, not able to afford borrowings at the current interest rates, and could have faced credit rationing if banks extend loans solely based on market perspectives. Notably, SMEs in the $8^{\text {th }}$ risk group appear to be able to afford higher payable interest rate in early-and mid-2000s than in 2009-10 but in both periods their borrowing costs were much lower.

15. In sum, credit support measures likely extended the life of non-viable SMEs. After the global financial crisis in FY2009-10 (blue color lines) firms' payable rates have shifted down, suggesting a general weakening of SME financial soundness. Borrowing costs and banks' breakeven rates, however, remained largely unchanged. This could imply that credit support measures over the decade (in FY2000 and in FY2005 relative to FY2009-10) have largely prevented a systemic tightening of financing conditions among SMEs across all risk groups, but at the same time, tended to protect SMEs in higher risk groups that could turn nonviable and should have exited or be restructured. Part of the risks was borne by various credit support measures beyond banks and SMEs. In the next section, we would discuss the close relation of the growth challenges of SMEs and various credit support measures.

\section{GrowTh Challenges OF SMEs: SLOW RESTRUCTURING AND LiMITED AVAILABILITY OF RISK CAPITAL}

\section{Despite their structural weaknesses, there have been only limited exits or} restructuring of nonviable SMEs (Figure 5). The entry and exit rates of SMEs are on average at about one-third of those in other advanced countries (Figure 6). In that regard, Japan has made efforts to improve corporate restructuring through reforms of insolvency laws. ${ }^{3}$ About 7,000 SMEs (less than 1 percent of total SMEs) have applied for business rehabilitation during 2000-09 under the new procedures but only 40 percent of those have achieved rehabilitation (JSBRI 2011).

\footnotetext{
${ }^{3}$ Following the enactment of the Civil Rehabilitation Act in 2000, the SME Revitalization Support Councils and the Business Rehabilitation Alternative Dispute Resolution System (ADR) were established. The Corporate Reorganization Act and the Bankruptcy Act were amended to facilitate restructuring. The Industrial Revitalization Corporation of Japan (IRCJ) operated during 2003-2007 to dispose of nonperforming loans and revitalize firms with excessive debts. Private equity and consulting firms also specialize in restructuring of distressed companies.
} 
Figure 5. Japan: Slow SME Restructuring

Areas of Concerns on Rehabilitation Support

(in percent of responses)

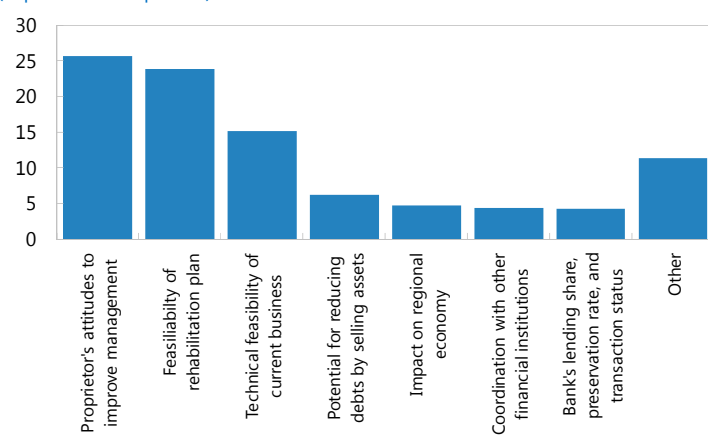

Source: Japan Small Business Research Institute Survey of SMEs

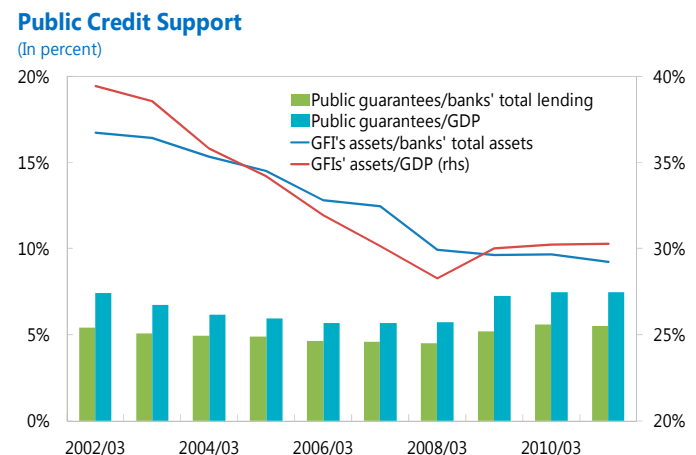

Sources: Bank of Japan and National Credit Guarantee Corporation

Loan modifications under the SME Financing Facilitation Act (Cumulative total; in number unless otherwise stated)

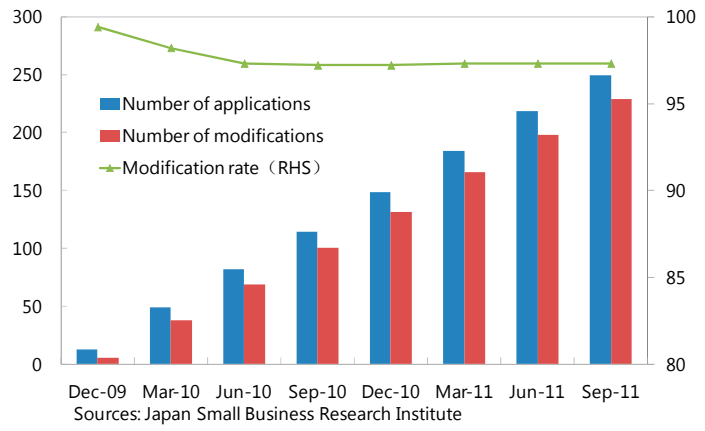

Key Areas for Improving SMEs Prospects

(in percent with multiple responses allowed)

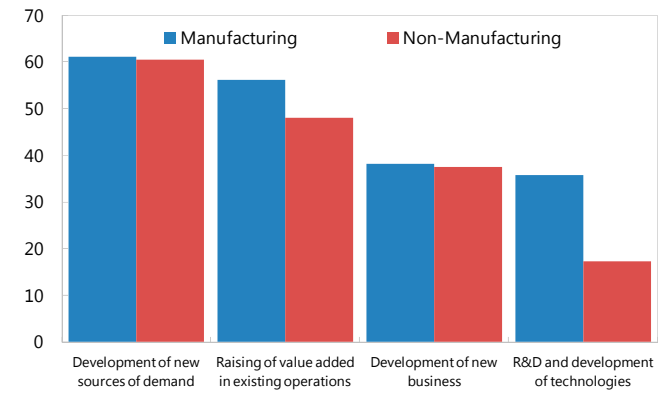

Source: Japan Small Business Research Institute
Obstacles to Continuation of Rehabilitation Support (in percent of multiple responses; after commencement)

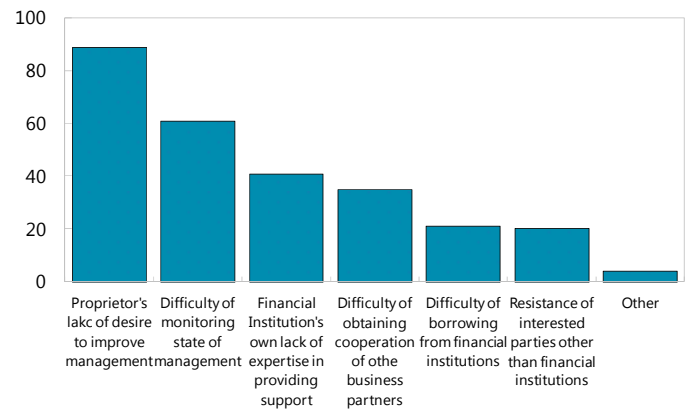

Source: Japan Small Business Research Institute Survey of SMEs

\section{SME Loans and Credit Guarantees}

(in tril lions of yen unl ess otherwise stated)

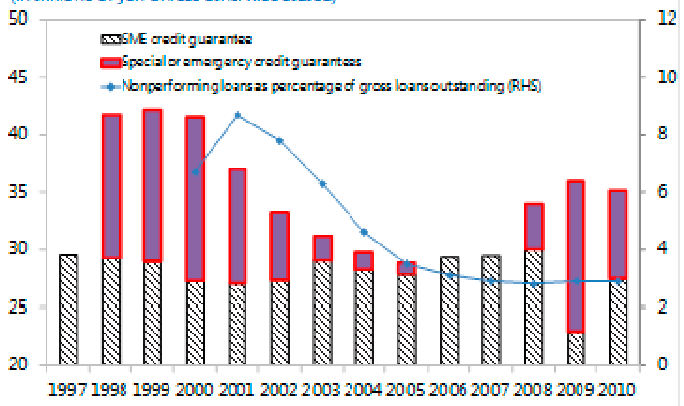

Sources; SME Agency, METL, BOJ, and lichiro and Koji (2006).

Cumulative Use of Safety-net Guarantees

(in trillions of yen unless otherwise stated)

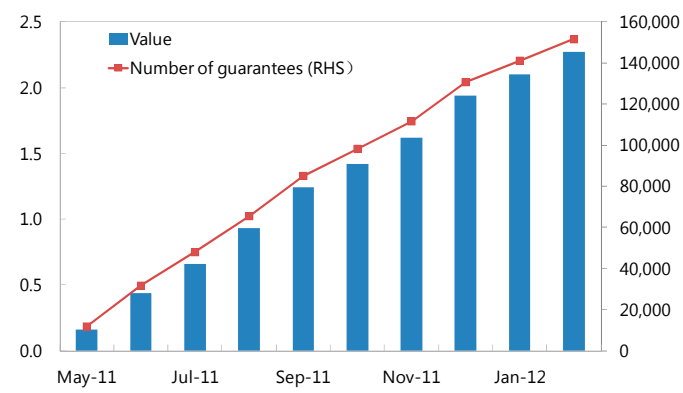

Source: Japan Small Business Research Institute

SME Support Measures - Effectiveness and Needs (In percent of responses)

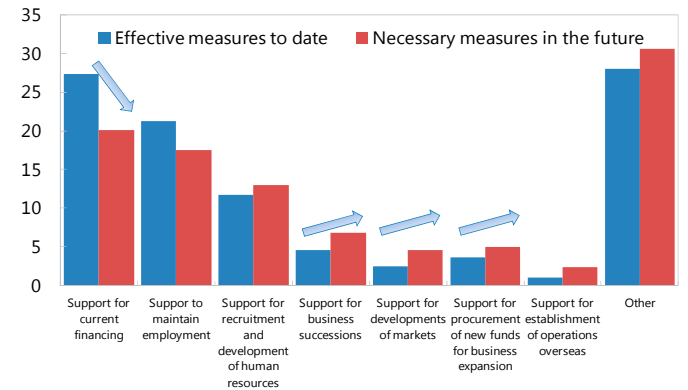

Sources: Japan Small Business Research Institute Survey of SMEs 
17. The structural weaknesses and the survival of nonviable SMEs could pose bottlenecks in credit intermediation and limit growth potentials. Low profitability and high leverage among SMEs, particularly in nonmanufacturing sector, could have limited credit demand as those SMEs are more reluctant to invest (Steinberg and Ogawa, 2009; Syed and Lee, 2010). Continued survival of nonviable SMEs could weaken credit risk assessment in banks and reduce credit availability to startups and other viable firms once credit demand picks up (Arping, Loranth, and Morrison, 2010; Uesugi, 2010; Sakai, Uesugi, and Watanabe 2010).

\section{A. Why Have SMEs Been Slow to Restructure?}

18. Creditors and nonviable SMEs have little incentive to restructure loans. The size of individual SME loans is usually small and makes it too costly to restructure on a case-bycase basis. In addition, recognizing the losses would reduce profit and capital, especially for smaller regional/shinkin banks that generally lack expertise in business restructuring, face higher nonperforming loan ratios (4-6 percent relative to 2 percent among major banks), and may not have strong capital base (Watanabe, 2012). ${ }^{4}$ More than half the larger (tier 1 ) regional banks and most small (tier 2) regional banks have capital adequacy ratios below that of the major banks (text figure). ${ }^{5}$ The existence of multiple creditors and the wide use of personal guarantees by SMEs adds to the difficulties in voluntary workouts or business transfers. Moreover, bankruptcy carries a high

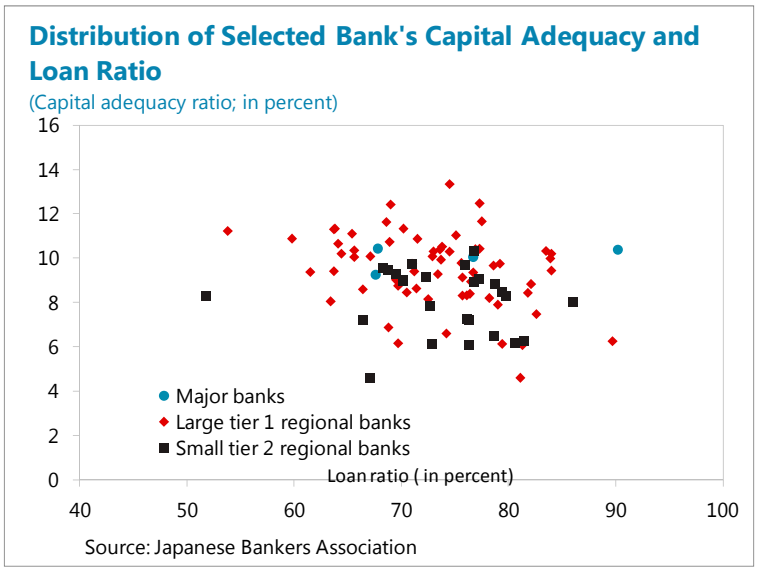
social stigma in Japan according to METI's surveys of SMEs.

19. Public credit support measures could also have weakened credit risk assessment and reduced the incentives to restructure (Figure 5). The measures were put in place after the global financial crisis and the Great East Japan Earthquake. They comprised an expansion of public credit guarantees, safety-net lending by government-affiliated financial institutions (GFIs), and temporary SME financing facilitation that was accompanied by a revision of the FSA's inspection manual and supervisory

\begin{tabular}{|c|c|c|}
\hline \multicolumn{3}{|c|}{ Table 4. Government Credit Guarantee Schemes } \\
\hline & $\begin{array}{l}\text { Standard Credit } \\
\text { Guarantees }\end{array}$ & $\begin{array}{c}\text { Special and Emergency Credit } \\
\text { Guarantees }\end{array}$ \\
\hline Guarantee limit & $\begin{array}{l}¥ 280 \text { million } \\
\text { of which: unsecured loans } \\
¥ 80 \text { million. }\end{array}$ & $¥ 280$ million \\
\hline Guarantee percentage & $\begin{array}{l}80 \text { percent of loans under } \\
\text { accountability-sharing } \\
\text { system }\end{array}$ & 100 percent \\
\hline Guarantee fees & 1.15 percent on average & about $0.8-1.0$ percent on average \\
\hline
\end{tabular}

\footnotetext{
${ }^{4}$ Most regional and shinkin banks have capital above the minimum requirement of 4 percent of risk-weighted assets (RWA) at present. The 2012 FSAP update stress tests suggest that the potential capital shortfall of small banks is small (about $3 / 4$ percent of GDP).

${ }^{5}$ Internationally active banks are subject to a minimum capital requirement of 8 percent of their risk weighted assets, while it is 4 percent for banks with mainly domestic activity.
} 
guidelines to relax the requirement of classifying restructured loans under the 'normal' category (Table 4). ${ }^{6}$ As a result, the size of public guarantees increased from about 4 to 6 percent of GDP over the past four years. These measures helped shelter existing firms from tighter credit conditions and limited the number of bankruptcies.

\section{The public credit support measures have, however, notable economic costs,} including by:

$>\quad$ Weakening credit risk assessment. Banks have less incentive to assess and take on credit risk under the support measures, as the guarantees covered a large share of the loan, in some cases up to 100 percent of the credit (Arping, Loranth, and Morrison, 2010; and Uesugi, 2010).

$>\quad$ Creating negative stigma. Over half of the SMEs that received some support (e.g., loan modification) noted in a survey that this would have a negative impact on their ability to obtain new borrowing, suggesting that the guarantees are not very effective in helping SMEs build their creditworthiness.

\section{Understating credit risk. Relaxing} the requirement of restructured loans to be classified as "normal" under the revision of guidelines and the SME Financing Facilitation Act could lead to an understatement of the true credit risk that banks face

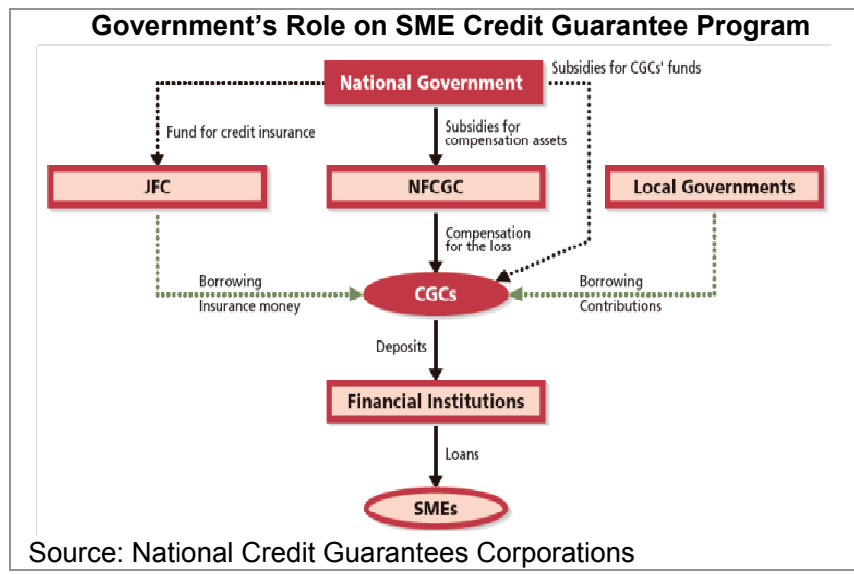
(text chart). According to the Bank of Japan, banks' NPL ratio would rise by about 1 percentage point if firms with restructured loans failed to recover. The problem appears more severe among regional banks and credit cooperatives as a higher proportion of their loans is reclassified under the Act (about 3-6 percent of total credit in regional banks and credit cooperatives relative to 1.7 percent in major banks). A previous special guarantee program in the late 1990s and early 2000s cost the government about $¥ 2$ trillion ( $1 / 2$ percent of GDP), large relative to the total credit guaranteed of $¥ 40$ trillion (Koo and Sasaki, 2010).

$>\quad$ Crowding out of nonguaranteed loans and limiting incentives to restructure SMEs. Keeping nonviable SMEs afloat through credit support measures could reduce credit supply for startups. The continued availability of credit support at low cost has cushioned nonviable SMEs from exits or restructuring as they face little pressures to

\footnotetext{
${ }^{6}$ The GFIs in the note refers to financial institutions that are publicly-held and those private financial institutions that remain affiliated with the government. For a complete list of support measures, please see SME White Paper 2011 by the Ministry of Economy, Trade, and Industry.
} 
restructure. Moreover, creditors are able to rollover guaranteed loans with borrowers without requiring business improvements that would be needed in case of restructuring. ${ }^{7}$

\section{Overall, the slow restructuring of SMEs is attributable to limited incentives and} some credit support measures. Besides idiosyncratic factor that bankruptcies in Japan carry higher cost as they are perceived to be failures, banks and SMEs have limited incentives for restructuring. Refinancing is easy at low interest rates, while recognizing losses would hit banks' profit and capital, especially for smaller regional/shinkin banks that generally lack expertise and face higher nonperforming loan ratios. Some credit support measures add to the difficulties in voluntary workouts or business transfers. The slow restructuring of SMEs has allowed the nonviable SMEs to stay afloat, which could impede credit intermediation and growth potentials, such as by limiting risk capital.

\section{B. Why is the Access and Availability of Risk-Based Capital Limited?}

\section{Availability of risk-based capital is very limited despite plenty of liquidity. Start-} ups rely predominantly on self-finance, but available funds (median value) raised from this source are small relative to other financing sources (Figure 6). Although there are no restrictions for raising venture capital funding, its availability is limited. In 2009, Japan ranked second to last in venture capital investment as a share of GDP among OECD countries. Business transfer rates, initial public offerings, and securitization of SME loans are also low by international standards.

\section{Several factors contribute to the limited availability of risk-based capital, including:}

The lack of timely credit information. While several credit registries are available, over half of surveyed financial institutions consider that assessing SME credit risks remains challenging due to limited information and untimely disclosure. ${ }^{8}$ Financial institutions often do not share credit information through credit registries, partly because of legal constraints and lack of an identification system in the absence of a tax identification number. These likely generated a financing gap for the 'middle-risk' group as large banks service low risk customers and lending companies engage in lending to high risk individuals, but leave out the middle-risk group (Schaede, 2005).

$>\quad$ Market practices. Banks' preference for fixed-asset collateral and personal guarantees in lending also tend to limit risk-based financing. Banks' lending decisions typically depend on collateral availability (often in fixed assets) and personal guarantees (unlimited liability subject to a maximum amount and duration) (Shirota, Imakubo, and

\footnotetext{
${ }^{7}$ At the same time, creditors decide whether to roll over the guaranteed loans considering various factors, such as the creditworthiness of borrowers.

${ }^{8}$ Credit registries in Japan include the Credit Risk Database (CRD), Risk Data Bank of Japan (RDB), Credit Risk Information Total Services (CRITS), and shinkin data bank (SDB). Financial institutions could also get access to credit risk databases from designated credit bureaus based on the Money Lending Business Act, such as Japan Credit Information Reference Center Corp. (JICC) and Credit Information Center (CIC). There appears to be no centralized credit bureau for consumer loans, such as late payment, bankruptcy and others, are shared between banks and consumer finance under the scheme, even they are owned by these banks), leaving scope for improving efficiency through information sharing.
} 
Nishioka, 2011). ${ }^{9}$ While these are common practices across countries, they appear more prevalent in Japan given its larger reliance on bank finance, and relatively less use of asset-based lending. Moreover, claims with personal guarantees are not easily transferable due to legal provisions. More than a quarter of SMEs consider the use of personal guarantees to be an obstacle to business transfers (JSBRI 2011).

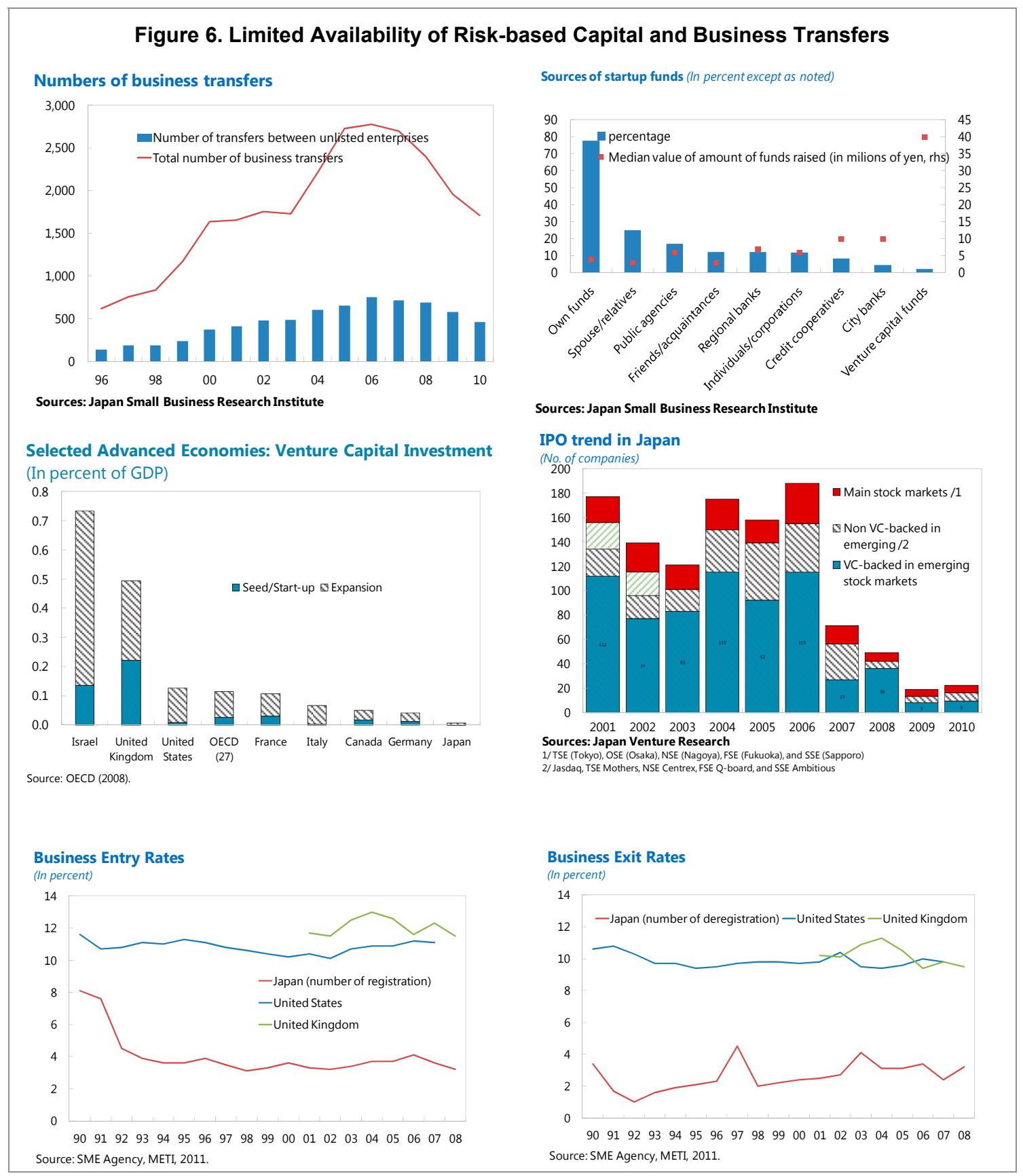

\footnotetext{
${ }^{9}$ Financial institutions often request a personal guarantee in financing to SMEs. In the past, guarantors often bore unlimited joint liabilities under blanket guarantee contracts, placing on excessive burden on guarantors. The Act for Partial Revision of the Civil Code came into effect in 2005 to rectify this by invalidating oral agreements, mandating contracts to stipulate maximum guarantee amounts, and limiting guarantee obligations to within five years (within three years when no period is specified).
} 
Limited provision of funds from institutional investors. Public pension funds have been restricted from investing in riskier assets. Japan's public pension funds differ from some other advanced countries in that regard, with a much higher share of assets in government bonds and no exposure to property or alternative investments (text figure).

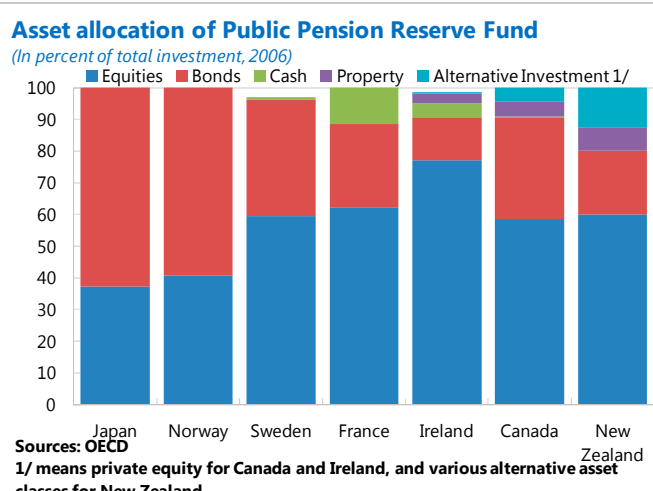

24. While efforts have been made to promote risk-based financing, their use by financial institutions has been limited. The GFIs and BOJ have begun to promote assetbased lending (ABL) but many financial institutions - particularly smaller regional/shinkin banks - have limited expertise in ABL (Figure 7). ${ }^{10}$ Financing based on account receivables is well established because nominal claims are easy to recognize although face the challenge of double assignment of the same claims. Difficulty in assessing a fair value has limited the availability of inventory-based and current-asset based financing (JSBRI 2011). Smaller banks, in particular, do not have the expertise to assess the fair value of certain types of collateral, such as inventory and intangible assets. The Act on Electronically Recorded Monetary Claims (ERMC) introduced in FY2007 may help stipulate rights on claims and avoid the risk of double assignment of claims, and thereby lift banks' lending to SMEs. However, banks need to incur sizeable investment and operating costs to make use of it.

25. Finally, risk appetite in the financial system is tepid. In Japan, household financial assets are about five times disposable income, the highest among the OECD. However, these financial assets are held in cash and deposits with financial institutions, who in turn allocate most of their assets to government securities (text charts). The low risk appetite largely reflects social preference in an aging society, risk-averse corporate governance, and weak economic conditions at present.

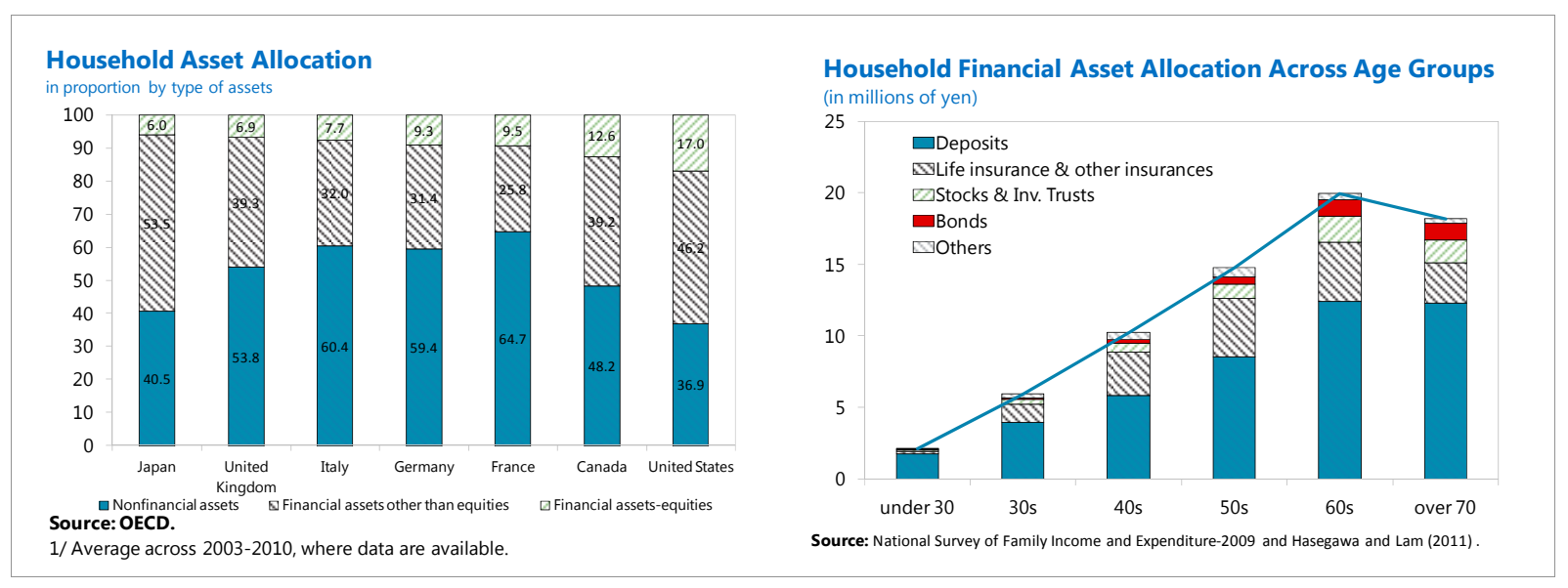

\footnotetext{
${ }^{10}$ Various GFIs have made efforts in promoting asset-based lending since 2007. The BOJ has revised its lending facility to support growth to include asset-based lending in 2011.
} 
Figure 7. Japan: Market Practices and Regulatory Factors that Limit Risk-based Capital

\begin{tabular}{lrcc}
\hline \multicolumn{1}{c}{ Economy } & Japan & $\begin{array}{c}\text { G-7 average } \\
\text { excl. Japan }\end{array}$ & $\begin{array}{c}\text { Selected Asian } \\
\text { economies 1/ }\end{array}$ \\
\hline Ease of Doing Business Rank & 20 & 27 & 7 \\
Starting a Business - Rank & 107 & 39 & 9 \\
Getting Credit - Rank & 24 & 33 & 7 \\
Protecting Investors - Rank & 17 & 44 & 37 \\
Enforcing Contracts - Rank & 34 & 43 & 9 \\
Resolving Insolvency - Rank & 1 & 23 & 12 \\
\hline
\end{tabular}

Source: World Bank (2012).

$1 /$ include Australia, Hong Kong, SAR, Korea, and Sinagpore

Effects of Personal Guarantee Obligations

(in percent of response)

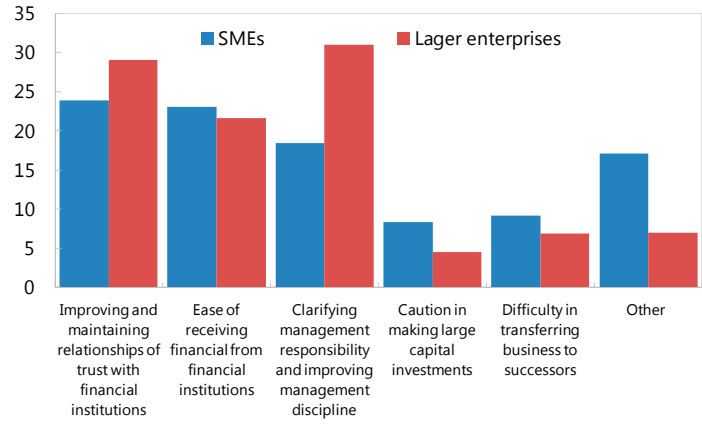

Source: Japan Small Business Research Institute Survey on SMEs Use Rate of Collateral and Personal Guarantees
(in percent of multiple responses)

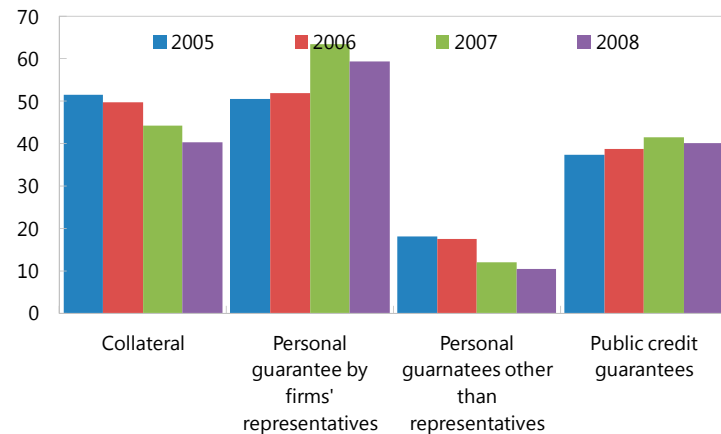

Source: Uesugi (2010)

New Methods of Financing and Usage (In percent of responses)

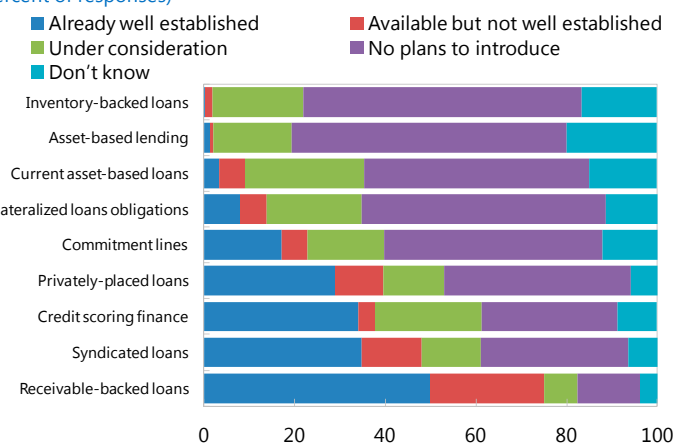

Source: Japan Small Business Research Institute (2006) Survey on SMEs

Obstacles Encounted during Business Transfers (in percent)

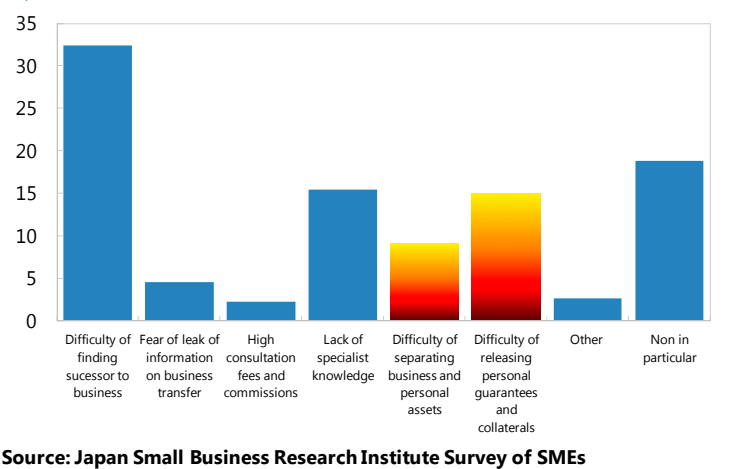

\section{Policy Options to Support Credit Growth}

\section{The factors contributing to slow credit growth in Japan are complicated and no} single reform will provide a silver bullet to jump start credit growth. The analysis in the above sections has identified several factors contributing to slow credit growth, including subdued macroeconomic conditions, firm deleveraging, and SME structural weakness. Several public support measures and market practices on lending have led to disincentives for restructuring and the provision of risk capital for startups. These impediments in credit 
channels would require comprehensive set of reforms and financial sector policies certainly play a key role.

27. Several financial policy measures could help foster a more dynamic SME sector and lift productivity. Specifically,

$>$ Gradually phase out credit support measures. Special credit guarantees with full coverage of the loan value need to be phased out as the recovery takes hold. Over time, reducing the normal guarantee coverage ratio from 80 to 60 percent in line with international averages (IMF, 2006) and scrutinizing the rollover of guarantees would ensure market discipline in monitoring credit risk by banks. Moreover, the temporary SME Financing Facilitation Act should also be phased out by March 2013, such that banks would not have an obligation (but still retain the option) to restructure loans at the request of SMEs. This would help limit restructured loans being reclassified as 'normal.'

$>\quad$ Encourage consolidation of regional and shinkin banks with low profitability by raising their capital requirements. Increasing the capital requirement for domesticoriented banks from 4 percent at present would facilitate consolidation. For instance, less than 5 percent of smaller banks would have a capital shortfall if the capital requirement for those banks was raised to 6 percent of risk-weighted assets (still below the minimum requirement of internationally-active banks at 8 percent). This may risk, in the near term, a contraction in credit as regional banks deleverage to meet the capital requirement, but the contraction could largely be mitigated by bringing in new capital through equity issuance, lower dividend payouts, or a temporary public capital injection. Over the medium term, higher capital would put these institutions in a stronger financial position to take on risk.

$>$ Accelerate SME restructuring. Consideration could be given to refocusing the public asset management company to advance SME restructuring. This would encourage the restructuring and exits of nonviable SMEs by using debt-equity swaps to incentivize banks and SMEs for out-of-court voluntary workouts (Laryea, 2010).

$>\quad$ Promote risk based financing by encouraging use of asset-based lending and deepening capital market developments. The authorities (government and municipalities) could take the lead in originating and trading electronically-registered claims for firms and households, which could avoid the risks of double assignment of claims. Current support to SMEs should be scaled down and better targeted by redirecting GFIs' lending away from reinsuring SME guarantees toward risk-based lending, as studies show startups obtaining GFIs' financing tend to outperform (Fukanuma, Tadanobu, and Watanabe, 2006). Capital markets for securitized loans could be developed further by revising the investment restrictions for institutional investors (e.g., pension funds) - once the supervision and regulatory framework is strengthened - to encourage alternative investments such as securitized loans and venture capital. This could improve long-term returns and help channel funds towards private investment, eventually lifting growth. 
$>$ Streamline regulatory measures to reduce the time and cost of starting businesses, particularly for business registration, which could promote business creation and transfers. Consideration could be given to broadening the coverage of credit registries through a more centralized database, and including a consumer data bureau for personal credit information. This could be facilitated by linking the proposed taxpayer identification system to the identification of credit information of firms and individuals.

28. Addressing structural weaknesses and accelerating SME restructuring could have a noticeable impact on the economy's growth potential. Based on simulations with the IMF's Global Integrated Monetary and Fiscal (GIMF) model, addressing SME structural weaknesses could raise aggregate productivity by about $1 / 4$ percentage points, which in turn would lift long-term growth by $0.1-0.2$ percentage points from the baseline. ${ }^{11}$

\section{CONCLUSION}

The paper outlines financial sector policies that help foster a dynamic SME sector and lift growth in Japan. While overall credit conditions have been accommodative, credit growth has remained weak, especially for small and medium-sized enterprises (SMEs). Many SMEs have faced structural challenges of high leverage and low profitability, which have worsened particularly for those with low credit worthiness during the global financial crisis. These challenges are closely related to low availability of risk-capital and several credit support measures. This paper argues that to encourage the supply of risk-based capital, costly government support measures should be phased out and SME restructuring be accelerated. Efforts are needed to deepen capital markets to enhance risk capital availability and address regulatory barriers to starting businesses. In that regard, addressing SME weaknesses would improve private investment, enhance firm productivity, and lift growth.

\footnotetext{
${ }^{11}$ The GIMF model is a multi-region dynamic general equilibrium model that analyzes the growth impact of an increase in productivity. If SME structural weaknesses were addressed, we would expect that the productivity of smaller firms would increase to about 80 percent of that of large firms. As a result, aggregate productivity would increase by $1 / 4$ percentage points.
} 


\section{REFERENCES}

Arping, S., G. Loranth, and A. Morrison, 2010, "Public Initiatives to Support Entrepreneurs: Credit Guarantees Versus Co-financing," Journal of Financial Stability, 6, pp. 26-35.

Ayyagrai, M., T. Beck, and A. Demirgüç-Kunt, 2005, “ Small and Medium Enterprises Across the Globe" in press. www.tilburguniversity.edu/webwijs/files/center/beck/.../globe.pdf

Bank of Japan, 2012, "Financial Systems Report," April and October 2012.

Caballero, R., T. Hoshi, and A. Kashyap, 2006 "Zombie Lending and Depressed Restructuring in Japan” NBER Working Paper, No. 12129.

Fukanuma, H., N. Tadanobu, and W. Watanabe, 2006, "Do Governmental Financial Institutions Help Startups Grow? Evidence from Japan,” Keio University Working Paper, November.

International Monetary Fund, 2006, Republic of Korea: Selected Issues, IMF Country Report No. 06/381 (Washington: International Monetary Fund).

Japan Financial System Council, 2009, "Overview of the Medium-term Vision for the Future of the Japanese Financial System," February.

Japan Small Business Research Institute, 2011, "White Paper on Small and Medium-sized Enterprises in Japan."

Jones, R. and M. Tsutsumi, 2009, "Financial Stability: Overcoming the Crisis and Improving the Efficiency of the Banking Sector in Japan," OECD Economics Department Working Papers No.738, December.

Koo R. and Sasaki M. (2010) ‘Japan’s Disposal of Bad Loans: Failure or Success,' Nomura Research Institute, 2010

Kwon, H.U., F. Narita, and M. Narita, 2009, "Resource Reallocation and Zombie Lending in Japan's 1990s", The Research Institute of Economy, Trade and Industry (REITI) Working Paper No.09-E-052.

Laryea T., 2010, “Approaches to Corporate Debt Restructuring in the Wake of Financial Crises," International Monetary Fund Staff Position Note, January.

Miyakawa, H., 2009, “Electronic Claims' Potential to Revolutionize Finance," Nomura Research Institute, Lakyara Vol.58, August.

Ogawa, K., S. Mika, and I. Tokutsu, 2012 “Japan Out of the Lost Decade: Divine Wind or Firms' Effort?” IMF Working Paper No. 12/171. 
Ono, A., K. Sakai, and I. Uesugi, 2008, "The Effects of Collateral on SME Performance in Japan, " RIETI Discussion Paper Series 08-E-037.

Sakai, K., I. Uesugi, T. Watanabe, 2010 "Firm Age and the Evolution of Borrowing Costs: Evidence from Japanese Small Firms" Journal of Banking \& Finance, Volume 34, Issue 8, August 2010, Pages 1970-1981.

Schaede, U., 2005, “The "Middle Risk Gap" and Financial System Reform: Small Firm Financing in Japan, Monetary and Economic Studies, February.

Shirota, T., K. Imakubo, and S. Nishioka, 2011, "Issues Surrounding the Financing of Small and Medium Enterprises-Liquidation of Receivables Through Asset-based Lending and Electronically Recorded Monetary Claims" Bank of Japan Review, June (in Japanese).

Steinberg, Chad and S. Ogawa, 2009, Current Challenges Facing SMEs in Japan, Japan Selected Issues, IMF Staff Country Report No. 09/211 (Washington: International Monetary Fund).

Syed, M. and J. Lee, 2010, Raising Medium-Term Growth" What Role Can Investment Play?, IMF Country Report No. 10/212 (Washington: International Monetary Fund).

Tokuda, H., 2011, "Searching for Clues to the Low Profitability and Competitiveness of Japanese SMEs: An Analysis Based upon International Comparisons," Mizuho Research Paper, No. 28.

Uesugi I., 2010, "The Impact of International Financial Crises on SMEs: The Case of Japan," Hitotsubashi University Working Paper.

Uesugi, I., 2008, "Efficiency of Credit Allocation and Effectiveness of Government Credit Guarantees: Evidence from Japanese Small Businesses,” Bank of Japan Working Paper Series, No.08-E-2, February.

Uesugi, I., K. Sakai, and G. Yamashiro, 2010, "The Effectiveness of Public Credit Guarantees in the Japanese Loan Market," January, Journal of Japanese and International Economy.

Watanabe. W., 2012, "The Bank Balance Sheet Effect on Loan Pricing and the Bank Size Evidence from Main Bank-SME Relationships in Japan,” Keio University Working Paper, February

World Bank Group, 2011, Doing Business 2012: Doing Business in a More Transparent World" 